\title{
Correction to: Meanings Attributed to Letters in Functional Contexts by Primary School Students
}

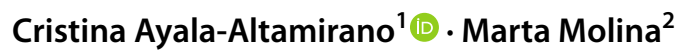

(c) The Author(s) 2021

\section{Correction to: International Journal of Science and Mathematics Education (2020) 18:1271-1291 https://doi.org/10.1007/s10763-019-10012-5}

The article Meanings Attributed to Letters in Functional Contexts by Primary School Students, written by Cristina Ayala-Altamirano and Marta Molina, was originally published Online First without Open Access. After publication in volume 18, issue 7, pages 1271-1291 the author decided to opt for Open Choice and to make the article an Open Access publication. Therefore, the copyright of the article has been changed to (C) The Author(s) 2021 and the article is forthwith distributed under the terms of the Creative Commons Attribution 4.0 International License, which permits use, sharing, adaptation, distribution and reproduction in any medium or format, as long as you give appropriate credit to the original author(s) and the source, provide a link to the Creative Commons licence, and indicate if changes were made. The images or other third party material in this article are included in the article's Creative Commons licence, unless indicated otherwise in a credit line to the material. If material is not included in the article's Creative Commons licence and your intended use is not permitted by statutory regulation or exceeds the permitted use, you will need to obtain permission directly from the copyright holder. To view a copy of this licence, visit http://creativecommons.org/licenses/by/4.0/.

The original article has been corrected.

The original article can be found online at https://doi.org/10.1007/s10763-019-10012-5.

Cristina Ayala-Altamirano

cayala.altamirano@gmail.com

Marta Molina

martamolina@usal.es

1 Universidad de Granada, Cuesta del Hospicio s/n, 18071 Granada, Spain

2 Universidad de Salamanca, Travesía Madrigal de Las Altas Torres, 3, 05003 Ávila, Spain 
Open Access This article is licensed under a Creative Commons Attribution 4.0 International License, which permits use, sharing, adaptation, distribution and reproduction in any medium or format, as long as you give appropriate credit to the original author(s) and the source, provide a link to the Creative Commons licence, and indicate if changes were made. The images or other third party material in this article are included in the article's Creative Commons licence, unless indicated otherwise in a credit line to the material. If material is not included in the article's Creative Commons licence and your intended use is not permitted by statutory regulation or exceeds the permitted use, you will need to obtain permission directly from the copyright holder. To view a copy of this licence, visit http://creativecommons.org/ licenses/by/4.0/. 